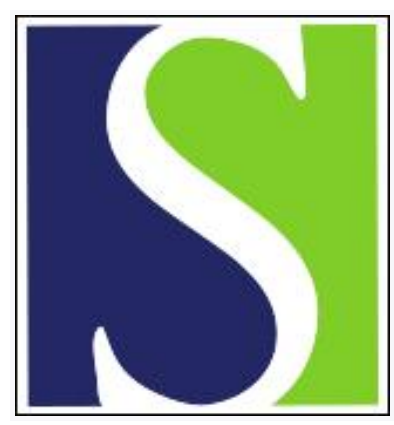

Scand J Work Environ Health 1998;24(3):197-205

https://doi.org/10.5271/sjweh.299

Issue date: Jun 1998

Psychosocial factors at work and subsequent depressive symptoms in the Gazel cohort

by Niedhammer I, Goldberg M, Leclerc A, Bugel I, David S

The following articles refer to this text: 2001;27(3):161-213;

2004;30(2):85-128; 2004;30(2):139-148; 2004;30(5):379-389;

2006;32(6):443-462; SJWEH Supplements 2008;(6):22-32;

2009;35(4):294-300

Key terms: depressive symptom; mental health; prospective study; psychosocial factor at work; social support at work

This article in PubMed: www.ncbi.nlm.nih.gov/pubmed/9710372 


\title{
Psychosocial factors at work and subsequent depressive symptoms in the Gazel cohort
}

\author{
by Isabelle Niedhammer, PhD, ${ }^{1}$ Marcel Goldberg, PhD, ${ }^{1}$ Annette Leclerc, PhD, ${ }^{1}$ Isabelle Bugel, BSc, ${ }^{1}$ \\ Simone David, $M S c^{1}$
}

\begin{abstract}
Niedhammer I, Goldberg M, Leclerc A, Bugel I, David S. Psychosocial factors at work and subsequent depressive symptoms in the Gazel cohort. Scand $J$ Work Environ Health 1998;24(3):197-205.
\end{abstract}

\begin{abstract}
Objective This study attempted to establish whether psychosocial factors at work are predictors of depressive symptoms in a prospective cohort of men and women employed in a wide variety of occupations by the French national company Electricité De France - Gaz De France (EDF-GDF).

Methods This prospective cohort study followed the Gazel cohort by means of annual self-administered questionnaires and independent data obtained from the medical and personnel departments of the company. The selfadministered questionnaire, in 1995, provided information about the psychosocial work environment characteristics, psychological job demands, decision latitude, and social support at work. Depressive symptoms were assessed by the Center for Epidemiologic Studies Depression (CES-D) Scale in the 1996 questionnaire. Potential confounding variables were age, marital status, and number of children, assessed in the 1995 questionnaire, stressful personal and occupational events during the previous 12 months, assessed in the 1996 questionnaire, and educational level, occupation and previous absenteeism for mental disorders, assessed from the independent data provided by EDFGDF. The subjects were 11552 workers ( 8422 men aged 46-56 years in 1995 and 3130 women aged 4156 years) who answered the 1995 and 1996 questionnaires and were working during this period.

Results High levels of psychological demands, low levels of decision latitude, and low levels of social support at work were significant predictors of subsequent depressive symptoms in both the men and the women. These results were unchanged after adjustment for potential confounding variables.

Conclusions The results strongly support the possibility that psychosocial factors at work are predictive of depressive symptoms.
\end{abstract}

Key terms depressive symptoms, mental health, prospective study, psychosocial factors at work, social support at work.

The consequences of mental disorders in the workplace are considerable in terms of cost and absenteeism $(1-3)$. It therefore seems important to identify the occupational risk factors for the development of mental disorders. The factors mentioned in previous studies include belonging to certain occupational categories, such as lawyers, teachers, counsellors and secretaries (4), job stress, mental load and strain due to schedule (5), lack of control over workplace, job unsuitability and poor human relations at the workplace (6), job demands, lack of autonomy, a difficult physical environment and dissatisfaction with co-workers (7), occupational events such as major changes in work content or organization (8), subjective evaluation of work conditions and social relationships at work (9).

Psychosocial factors at work, especially job strain defined by a combination of high levels of psychological demands and low levels of decision latitude, have been widely mentioned as important contributors to cardiovascular disease (10). The relationship between psychosocial factors at work and mental health has more rarely been explored. Some studies have shown that job strain was associated with mental disorders $(11-16)$; others, that it was not $(17,18)$. Bourbonnais et al explored the potential stress-buffering effect of social support at work, but did not confirm it (15). Bromet et al (17) reported that job demands and their interaction with co-worker support were important predictors of affective disorders. However, very few of the studies concerned were longitudinal $(17,18)$ or adjusted their data for potential confounding factors.

Although previous studies differed in terms of both study design and methods used to assess psychosocial work environment and mental health status, they do

INSERM (National Research Institute on Health and Medicine), Unit 88, Hôpital National de Saint-Maurice, Saint-Maurice, France.

Reprint requests to: Dr I Niedhammer, INSERM U88, Hôpital National de Saint-Maurice, 14 rue du Val d'Osne, F-94415 Saint-Maurice Cedex, France. [e-mail: i.niedhammer@st-maurice.inserm.fr] 
suggest that psychosocial factors at work are risk factors for mental disorders and depression.

The objective of the present study was to establish whether psychosocial factors at work (ie, psychological demands, decision latitude, and social support at work) are predictive of subsequent depressive symptoms in a cohort of men and women employed in a wide variety of occupations at the French national company Electricité De France - Gaz De France (EDF-GDF).

Table 1. Personal characteristics of the sample.

\begin{tabular}{|c|c|c|c|c|}
\hline \multirow[t]{2}{*}{ Characteristic } & \multicolumn{2}{|c|}{$\begin{array}{c}\text { Men } \\
(N=8422)\end{array}$} & \multicolumn{2}{|c|}{$\begin{array}{c}\text { Women } \\
(N=3130)\end{array}$} \\
\hline & $N$ & $\%$ & $N$ & $\%$ \\
\hline \multicolumn{5}{|l|}{$\begin{array}{l}\text { Age group } \\
\text { (years) }^{a}\end{array}$} \\
\hline $\begin{array}{l}41-44 \\
45-49 \\
50-54 \\
55-56\end{array}$ & $\begin{array}{r}- \\
3933 \\
4020 \\
469\end{array}$ & $\begin{array}{r}46.7 \\
47.7 \\
5.6\end{array}$ & $\begin{array}{r}791 \\
1373 \\
822 \\
144\end{array}$ & $\begin{array}{r}25.3 \\
43.9 \\
26.2 \\
4.6\end{array}$ \\
\hline \multicolumn{5}{|l|}{$\begin{array}{l}\text { Marital } \\
\text { status }^{a}\end{array}$} \\
\hline $\begin{array}{l}\text { Married } \\
\text { Single } \\
\text { Cohabiting } \\
\text { Separated } \\
\text { Divorced } \\
\text { Widowed }\end{array}$ & $\begin{array}{r}7498 \\
177 \\
278 \\
86 \\
313 \\
67\end{array}$ & $\begin{array}{r}89.1 \\
2.1 \\
3.3 \\
1.0 \\
3.7 \\
0.8\end{array}$ & $\begin{array}{r}2147 \\
216 \\
202 \\
58 \\
396 \\
111\end{array}$ & $\begin{array}{r}68.6 \\
6.9 \\
6.5 \\
1.9 \\
12.6 \\
3.5\end{array}$ \\
\hline \multicolumn{5}{|l|}{$\begin{array}{l}\text { Number of } \\
\text { children }^{2}\end{array}$} \\
\hline $\begin{array}{r}0 \\
1 \\
2 \\
\geq 3\end{array}$ & $\begin{array}{r}441 \\
1569 \\
3860 \\
2495\end{array}$ & $\begin{array}{r}5.3 \\
18.8 \\
46.1 \\
29.8\end{array}$ & $\begin{array}{r}345 \\
900 \\
1505 \\
353\end{array}$ & $\begin{array}{l}11.1 \\
29.0 \\
48.5 \\
11.4\end{array}$ \\
\hline \multicolumn{5}{|l|}{$\begin{array}{l}\text { Educational } \\
\text { level a }\end{array}$} \\
\hline $\begin{array}{l}\text { Primary } \\
\text { Lower vocational } \\
\text { Lower secondary } \\
\text { Upper secondary } \\
\text { Upper vocational } \\
\text { University }\end{array}$ & $\begin{array}{r}364 \\
4258 \\
1057 \\
555 \\
600 \\
1587\end{array}$ & $\begin{array}{r}4.3 \\
50.6 \\
12.6 \\
6.6 \\
7.1 \\
18.8\end{array}$ & $\begin{array}{r}195 \\
1512 \\
591 \\
376 \\
175 \\
281\end{array}$ & $\begin{array}{r}6.2 \\
48.3 \\
18.9 \\
12.0 \\
5.6 \\
9.0\end{array}$ \\
\hline \multicolumn{5}{|l|}{$\begin{array}{l}\text { Previous } \\
\text { absenteeism } \\
\text { for mental } \\
\text { disorders }^{b}\end{array}$} \\
\hline $\begin{array}{l}\text { No } \\
\text { Yes }\end{array}$ & $\begin{array}{r}8335 \\
87\end{array}$ & $\begin{array}{r}99.0 \\
1.0\end{array}$ & $\begin{array}{r}2977 \\
153\end{array}$ & $\begin{array}{r}95.1 \\
4.9\end{array}$ \\
\hline \multicolumn{5}{|l|}{$\begin{array}{l}\text { Stressful } \\
\text { personal } \\
\text { events c }\end{array}$} \\
\hline $\begin{array}{r}0 \\
1 \\
2 \\
\geq 3\end{array}$ & $\begin{array}{r}4140 \\
2908 \\
1084 \\
290\end{array}$ & $\begin{array}{r}49.2 \\
34.5 \\
12.9 \\
3.4\end{array}$ & $\begin{array}{r}1524 \\
1086 \\
384 \\
136\end{array}$ & $\begin{array}{r}48.7 \\
34.7 \\
12.3 \\
4.3\end{array}$ \\
\hline \multicolumn{5}{|l|}{$\begin{array}{l}\text { Depressive } \\
\text { symptoms }^{d}\end{array}$} \\
\hline $\begin{array}{l}\text { No } \\
\text { Yes }\end{array}$ & $\begin{array}{l}5370 \\
1780\end{array}$ & $\begin{array}{l}75.1 \\
24.9\end{array}$ & $\begin{array}{r}1818 \\
703\end{array}$ & $\begin{array}{l}72.1 \\
27.9\end{array}$ \\
\hline $\begin{array}{l}\text { In } 1995 . \\
\text { Sickness absenteeism } \\
\text { the filling out of the } 1 \\
\text { Events that occurred } \\
\text { the } 1996 \text { questionnai } \\
\text { In } 1996 \text {. }\end{array}$ & $\begin{array}{l}\text { menta } \\
\text { questi } \\
\text { ig the }\end{array}$ & $\begin{array}{l}\text { ders d } \\
\text { re. } \\
\text { us } 12 \text { r }\end{array}$ & $\begin{array}{l}12 \mathrm{~m} \\
\text { and we }\end{array}$ & recedi \\
\hline
\end{tabular}

\section{Subjects and methods}

\author{
Study population
}

The population included 20624 subjects working at EDFGDF, comprising men aged $40-50$ years and women aged 35-50 years at the beginning of the study. They were members of the Gazel cohort, which was established in January $1989(19,20)$. Since then, this cohort has been followed by means of a yearly self-administered questionnaire and also the collection of independent data from the personnel and medical departments of EDF-GDF. Research on aspects of health other than mental health has been conducted in the same cohort. (See, for example, references $21-24$.) The study population comprised subjects who answered the 1995 and 1996 questionnaires and were working during this period (ie, 11552 persons).

\section{Psychosocial factors at work}

In 1995, the self-administered questionnaire included 16 items concerning the psychosocial aspects of work. The items were selected from 2 sources $(12,25,26)$ as being particularly suitable for measuring job stress in a heterogeneous population. Three psychosocial work factors were used (appendix): psychological demands (a 5-item indicator measuring job demands, time pressure and conflicting demands), decision latitude (a 6-item indicator measuring the subject's influence on or control over his or her work, job variety, and the possibilities for learning new skills), and social support at work (a 5-item indicator measuring contacts with co-workers during work and leisure). Factorial validity was evaluated by a principal factor analysis with orthogonal Varimax rotation; our results were consistent with the dimensions expected from the theory. As regards internal consistency, Cronbach's alpha coefficient was 0.69 for psychological demands, 0.65 for decision latitude, and 0.52 for social support at work. The values for all the items concerning each index were summed, and the summary distribution of values for each index was then dichotomized by the median, for use in the analyses.

\section{Depressive symptoms}

In the 1996 questionnaire, the CES-D scale (Center for Epidemiologic Studies - Depression Scale) was included $(27,28)$. This scale consists of 20 questions describing symptoms and behavior connected with depression, and a total score is computed from the replies graded from 0 to 3 . The thresholds established for the French population $-\geq 17$ for men and $\geq 23$ for women - identify subjects with severe depressive symptoms (29). These thresholds were used in the present study. 


\section{Personal and occupational characteristics}

Personal characteristics based on the self-administered questionnaire of 1995 comprised age, marital status, and number of children. Information concerning educational level and occupation was supplied by the personnel department of EDF-GDF. Absenteeism for depressive or anxiety disorders during the 12 months preceding the filling out of the self-administered questionnaire in 1995 was assessed from sickness absenteeism data provided by EDF-GDF (30), and it was used in the analysis because of the long-standing nature of these disorders. The selfadministered questionnaire of 1996 included questions on stressful personal and occupational events during the preceding 12 months. Twelve items concerned personal events (death of a spouse, divorce, marital separation, death of a close relative, etc) and 4 concerned occupational events (job change, transfer, reconversion, or department restructuring). These items were adapted from the Social Readjustment Rating Scale (31).

\section{Statistical methods}

The crude relationships between the 3 psychosocial factors at work in 1995 and depressive symptoms a year later were submitted to Pearson's chi-square test. Logistic regression analysis was then used to adjust for confounding variables. Depressive symptoms in 1996 were used as the dependent variable and the 3 psychosocial factors at work assessed in 1995 were used as independent variables. Adjustment was made for personal and occupational characteristics, which included age, marital status, number of children, educational level, occupation, previous absenteeism for mental disorders, and stressful personal and occupational events. The 3 psychosocial factors at work were introduced simultaneously into the models to assess their own effect. Interactions were also examined by including the three 2-way interaction terms high demands and low latitude, high demands and low support, and low latitude and low support, and the 3-way interaction term high demands, low latitude and low support. These interaction terms were selected a priori on the basis of the theoretical assumptions of Karasek's model $(11,12,25,26)$. Separate analyses were carried out for the men and women. Statistical analysis was performed using SAS (32) and BMDP (33) statistical software packages.

\section{Results}

Between 1989 and 1995, 222 of the subjects in the initial cohort of 20624 died, 2365 retired, and 38 left the company. Of the 17999 subjects still working in 1995, 13406
(74\%) answered the 1995 self-administered questionnaire. One hundred and eighty subjects were excluded from the study because they were not working because of sickness absence, long illness, or disability when the 1995 questionnaire had to be completed. By 1996, another 23 had died, 671 had retired, and 2 had left the company. Of the 12530 subjects still working in $1996,11552(92 \%)$ answered the 1996 questionnaire, $920(7 \%)$ did not, and 58 (1\%) did but were absent from work because of sickness absence, long illness, or disability. The nonrespondents to the 1995 or 1996 questionnaires differed significantly from the respondents as regards educational and occupational levels. The present study was restricted to the 11552 subjects, comprising 8422 men and 3130 women, who answered both the 1995 and 1996 questionnaires and were working during this period. Further details concerning this population's personal and occupational characteristics are given in tables 1 and 2, respectively. As regards psychosocial factors at work, the mean score for psychological demands (the higher the score, the higher the psychological demands) was significantly higher for the men than

Table 2. Occupational characteristics of the sample.

\begin{tabular}{|c|c|c|c|c|}
\hline \multirow[t]{2}{*}{ Characteristic } & \multicolumn{2}{|c|}{$\begin{array}{c}\text { Men } \\
(\mathrm{N}=8422)\end{array}$} & \multicolumn{2}{|c|}{$\begin{array}{l}\text { Women } \\
(\mathrm{N}=3130)\end{array}$} \\
\hline & $N$ & $\%$ & 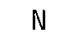 & $\%$ \\
\hline \multicolumn{5}{|l|}{ Occupation ${ }^{2}$} \\
\hline $\begin{array}{l}\text { Teaching and health } \\
\text { professionals } \\
\text { Managers } \\
\text { Engineers } \\
\text { Health and social work }\end{array}$ & $\begin{array}{r}109 \\
1453 \\
1951\end{array}$ & $\begin{array}{r}1.3 \\
17.3 \\
23.2\end{array}$ & $\begin{array}{r}- \\
219 \\
168\end{array}$ & $\begin{array}{c}0 \\
7.0 \\
5.4\end{array}$ \\
\hline $\begin{array}{l}\text { associate professionals } \\
\text { Administrative }\end{array}$ & - & 0 & 65 & 2.1 \\
\hline $\begin{array}{l}\text { associate professionals } \\
\text { Physical, engineering } \\
\text { and life science }\end{array}$ & 998 & 11.9 & 1752 & 56.2 \\
\hline associate professionals & 478 & 5.7 & - & 0 \\
\hline Foremen & 2539 & 30.3 & 334 & 10.7 \\
\hline Clerks & 227 & 2.7 & 580 & 18.6 \\
\hline $\begin{array}{l}\text { Skilled industrial } \\
\text { workers }\end{array}$ & 332 & 4.0 & - & 0 \\
\hline Craftsmen & 306 & 3.6 & - & 0 \\
\hline \multicolumn{5}{|l|}{$\begin{array}{l}\text { Stressful occupational } \\
\text { events }\end{array}$} \\
\hline 0 & 6085 & 72.2 & 2308 & 73.8 \\
\hline 1 & 1742 & 20.7 & 599 & 19.1 \\
\hline$\geq 2$ & 595 & 7.1 & 223 & 7.1 \\
\hline \multicolumn{5}{|l|}{$\begin{array}{l}\text { Level of psychological } \\
\text { demands }{ }^{a}\end{array}$} \\
\hline Low & 4442 & 54.7 & 1277 & 43.5 \\
\hline High & 3674 & 45.3 & 1657 & 56.5 \\
\hline \multicolumn{5}{|l|}{$\begin{array}{l}\text { Level of decision } \\
\text { latitude }^{\text {a }}\end{array}$} \\
\hline High & 4135 & 50.6 & 1428 & 48.0 \\
\hline Low & 4033 & 49.4 & 1546 & 52.0 \\
\hline \multicolumn{5}{|l|}{$\begin{array}{l}\text { Level of social support } \\
\text { at work }^{a}\end{array}$} \\
\hline High & 4000 & 48.5 & 1408 & 46.2 \\
\hline Low & 4255 & 51.5 & 1640 & 53.8 \\
\hline
\end{tabular}

a In 1995.

${ }^{b}$ Events that occurred during the previous 12 months and were reported in the 1996 questionnaire. 
for the women, 12.4 (SD 2.5) versus 12.2 (SD 2.6). For decision latitude (the higher the score, the higher the decision latitude), the mean score was also higher for the men than for the women, 17.4 (SD 2.5) versus 16.2 (SD 2.8 ). For social support at work (the higher the score, the higher the social support), the mean score was higher for the men than for the women, 15.4 (SD 2.4) versus 14.4 (SD 2.4).

The distribution of the CES-D score strongly differed between the men and women. The mean score was significantly higher for the women than the men with higher variance for the women, 17.3 (SD 10.5) versus 12.4 (SD 7.9). The prevalence of depressive symptoms, defined by the cut-off limits of 17 (for the men) and 23 (for the women), was $24.9 \%$ for the men and $27.9 \%$ for the women in 1996 (table 1). Age and the number of children were not associated with the depressive symptoms of the men or women (table 3). Marital status was associated with depressive symptoms; men and women who were separated, divorced or widowed in 1995, as well as single men, were more likely to have depressive symptoms a year later. Educational level was only related to depressive symptoms among the women; the higher the level, the less they suffered from such symptoms. The presence of stressful personal events during the previous 12 months markedly raised the prevalence of subsequent depressive symptoms among both the men and the women. This prevalence also rose for both genders with previous absenteeism for mental disorders. All the occupational factors explored (ie, occupation, stressful occupational events and the 3 psychosocial factors at work) were strongly related to the subsequent development of depressive symptoms among the men and women (table 4). High levels of psychological demands, low levels of decision latitude, and low

Table 3. Personal characteristics and subsequent depressive symptoms. (NS = not significant)

\begin{tabular}{|c|c|c|c|c|c|c|}
\hline \multirow[t]{2}{*}{ Characteristics } & \multicolumn{3}{|c|}{ Men } & \multicolumn{3}{|c|}{ Women } \\
\hline & $\begin{array}{c}\text { Without } \\
\text { depressive } \\
\text { symptoms } \\
(\mathrm{N})\end{array}$ & $\begin{array}{c}\text { With } \\
\text { depressive } \\
\text { symptoms } \\
\text { (N) }\end{array}$ & Cases $(\%)$ & $\begin{array}{l}\text { Without } \\
\text { derpessive } \\
\text { symptoms } \\
\text { (N) }\end{array}$ & $\begin{array}{l}\text { With } \\
\text { depressive } \\
\text { symptoms } \\
\text { (N) }\end{array}$ & Cases $(\%)$ \\
\hline \multicolumn{7}{|l|}{ Age groups (years) } \\
\hline $\begin{array}{l}41-44 \\
45-49 \\
50-54 \\
55-56\end{array}$ & $\begin{array}{r}2530 \\
2535 \\
305\end{array}$ & $\begin{array}{r}- \\
844 \\
846 \\
90\end{array}$ & $\begin{array}{r}0 \\
25.0 \\
25.0 \\
22.8 \\
\text { NS }\end{array}$ & $\begin{array}{r}510 \\
769 \\
466 \\
73\end{array}$ & $\begin{array}{r}182 \\
331 \\
161 \\
29\end{array}$ & $\begin{array}{r}26.3 \\
30.1 \\
25.7 \\
28.4 \\
\text { NS }\end{array}$ \\
\hline \multicolumn{7}{|l|}{ Marital status } \\
\hline $\begin{array}{l}\text { Married } \\
\text { Single } \\
\text { Cohabiting } \\
\text { Separated } \\
\text { Divorced } \\
\text { Widowed }\end{array}$ & $\begin{array}{r}4854 \\
87 \\
186 \\
37 \\
164 \\
41\end{array}$ & $\begin{array}{r}1509 \\
50 \\
57 \\
35 \\
105 \\
22\end{array}$ & $\begin{array}{c}23.7 \\
36.5 \\
23.5 \\
48.6 \\
39.0 \\
34.9 \\
\star \star \star\end{array}$ & $\begin{array}{r}1267 \\
134 \\
116 \\
28 \\
217 \\
56\end{array}$ & $\begin{array}{r}438 \\
49 \\
53 \\
22 \\
109 \\
32\end{array}$ & $\begin{array}{l}25.7 \\
26.8 \\
31.4 \\
44.0 \\
33.4 \\
36.4 \\
\star * *\end{array}$ \\
\hline \multicolumn{7}{|l|}{ Number of children } \\
\hline $\begin{array}{r}0 \\
1 \\
2 \\
\geq 3\end{array}$ & $\begin{array}{r}259 \\
989 \\
2492 \\
1595\end{array}$ & $\begin{array}{l}109 \\
319 \\
810 \\
527\end{array}$ & $\begin{array}{r}29.6 \\
24.4 \\
24.5 \\
24.8 \\
\text { NS }\end{array}$ & $\begin{array}{l}211 \\
533 \\
858 \\
203\end{array}$ & $\begin{array}{r}66 \\
188 \\
349 \\
91\end{array}$ & $\begin{array}{r}23.8 \\
26.1 \\
28.9 \\
31.0 \\
\text { NS }\end{array}$ \\
\hline \multicolumn{7}{|l|}{ Educational level } \\
\hline $\begin{array}{l}\text { Primary } \\
\text { Lower vocational } \\
\text { Lower secondary } \\
\text { Upper secondary } \\
\text { Upper vocational } \\
\text { University }\end{array}$ & $\begin{array}{r}203 \\
2693 \\
645 \\
341 \\
400 \\
1087\end{array}$ & $\begin{array}{r}72 \\
891 \\
241 \\
131 \\
118 \\
327\end{array}$ & $\begin{array}{r}26.2 \\
24.9 \\
27.2 \\
27.8 \\
22.8 \\
23.1 \\
\text { NS }\end{array}$ & $\begin{array}{l}102 \\
847 \\
338 \\
227 \\
107 \\
197\end{array}$ & $\begin{array}{r}44 \\
364 \\
137 \\
83 \\
33 \\
42\end{array}$ & $\begin{array}{l}30.1 \\
30.1 \\
28.8 \\
26.8 \\
23.6 \\
17.6 \\
* *\end{array}$ \\
\hline \multicolumn{7}{|l|}{$\begin{array}{l}\text { Previous absenteeism } \\
\text { for mental disorders }\end{array}$} \\
\hline $\begin{array}{l}\text { No } \\
\text { Yes }\end{array}$ & $\begin{array}{r}5347 \\
23\end{array}$ & $\begin{array}{r}1732 \\
48\end{array}$ & $\begin{array}{l}24.5 \\
67.6 \\
\star \star \star\end{array}$ & $\begin{array}{r}1755 \\
63\end{array}$ & $\begin{array}{r}648 \\
55\end{array}$ & $\begin{array}{r}27.0 \\
46.6 \\
\star * \star\end{array}$ \\
\hline \multicolumn{7}{|l|}{ Stressful personal events } \\
\hline $\begin{array}{r}0 \\
1 \\
2 \\
\geq 3\end{array}$ & $\begin{array}{r}2622 \\
1906 \\
668 \\
174\end{array}$ & $\begin{array}{r}756 \\
641 \\
297 \\
86\end{array}$ & $\begin{array}{l}22.4 \\
25.2 \\
30.8 \\
33.1 \\
\star \star \star\end{array}$ & $\begin{array}{r}913 \\
628 \\
217 \\
60\end{array}$ & $\begin{array}{r}260 \\
269 \\
116 \\
58\end{array}$ & $\begin{array}{l}22.2 \\
30.0 \\
34.8 \\
49.2 \\
\star \star \star\end{array}$ \\
\hline
\end{tabular}

${ }^{*} P<0.05,{ }^{* *} P<0.01,{ }^{* *} P<0.001$. 
levels of social support at work increased the risk of subsequent depressive symptoms. Age, marital status, educational level, occupation, previous absenteeism for mental disorders, and stressful personal and occupational events were taken as confounding variables in the multivariate analysis.

The results of the logistic regression analyses (table 5) showed that high levels of psychological demands and low levels of decision latitude and social support at work significantly raised the risk of subsequent depressive symptoms among the men and women after adjustment for potential confounding variables. However, no significant interaction was found between psychological demands, decision latitude, and social support at work in relation to depressive symptoms. The other variables included in the models were significantly related to these symptoms, except for age and educational level.

\section{Discussion}

This prospective study showed that the 3 psychosocial factors at work comprising psychological demands, desion latitude, and social support at work were significant predictors of subsequent depressive symptoms of men and

Table 4. Occupational factors and subsequent depressive symptoms.

\begin{tabular}{|c|c|c|c|c|c|c|}
\hline \multirow[t]{2}{*}{ Occupational factor } & \multicolumn{3}{|c|}{ Men } & \multicolumn{3}{|c|}{ Women } \\
\hline & $\begin{array}{l}\text { Without } \\
\text { depressive } \\
\text { symptoms } \\
(\mathrm{N})\end{array}$ & $\begin{array}{l}\text { With } \\
\text { depressive } \\
\text { symptoms } \\
\text { (N) }\end{array}$ & Cases (\%) & $\begin{array}{l}\text { Without } \\
\text { depressive } \\
\text { symptoms } \\
\text { (N) }\end{array}$ & $\begin{array}{l}\text { With } \\
\text { depressive } \\
\text { symptoms } \\
\text { (N) }\end{array}$ & Cases (\%) \\
\hline \multicolumn{7}{|l|}{ Occupation } \\
\hline $\begin{array}{l}\text { Teaching and health } \\
\text { professionals }\end{array}$ & 72 & 24 & 25.0 & - & - & 0 \\
\hline Managers & 994 & 276 & 21.7 & 155 & 30 & 16.2 \\
\hline Engineers & 1351 & 367 & 21.4 & 121 & 21 & 14.8 \\
\hline $\begin{array}{l}\text { Health and social } \\
\text { work associate } \\
\text { professionals }\end{array}$ & - & - & 0 & 43 & 9 & 17.3 \\
\hline $\begin{array}{l}\text { Administrative } \\
\text { associate professionals }\end{array}$ & 595 & 237 & 28.5 & 994 & 419 & 29.6 \\
\hline $\begin{array}{l}\text { Physical, engineering, } \\
\text { life science associate } \\
\text { professionals }\end{array}$ & 285 & 104 & 26.7 & - & - & 0 \\
\hline Foremen & 1580 & 552 & 25.9 & 195 & 71 & 26.7 \\
\hline Clerks & 117 & 57 & 32.8 & 303 & 149 & 33.0 \\
\hline Skilled industrial workers & 194 & 75 & 27.9 & - & - & 0 \\
\hline Craftsmen & 163 & 81 & $\begin{array}{r}33.2 \\
* * *\end{array}$ & - & - & $\begin{array}{r}0 \\
* * *\end{array}$ \\
\hline \multicolumn{7}{|l|}{ Stressful occupational events } \\
\hline 0 & 3968 & 1138 & 22.3 & 1368 & 452 & 24.8 \\
\hline 1 & 1042 & 475 & 31.3 & 334 & 169 & 33.6 \\
\hline$\geq 2$ & 360 & 167 & $\begin{array}{r}31.7 \\
* * *\end{array}$ & 116 & 82 & $\begin{array}{l}41.4 \\
* * *\end{array}$ \\
\hline \multicolumn{7}{|l|}{ Levels of psychological demands } \\
\hline Low & 3026 & 764 & 20.2 & 771 & 249 & 24.4 \\
\hline High & 2186 & 958 & $\begin{array}{r}30.5 \\
* * *\end{array}$ & 965 & 416 & $\begin{array}{r}30.1 \\
\star \star\end{array}$ \\
\hline \multicolumn{7}{|l|}{ Levels of decision latitude } \\
\hline High & 2821 & 763 & 21.3 & 899 & 268 & 23.0 \\
\hline Low & 2417 & 971 & $\begin{array}{r}28.7 \\
\star \star \star\end{array}$ & 842 & 399 & $\begin{array}{r}32.2 \\
* * *\end{array}$ \\
\hline \multicolumn{7}{|l|}{ Levels of social support at work } \\
\hline High & 2776 & 680 & 19.7 & 869 & 287 & 24.8 \\
\hline Low & 2501 & 1069 & $\begin{array}{c}29.9 \\
\star \star \star\end{array}$ & 909 & 397 & $\begin{array}{r}30.4 \\
* *\end{array}$ \\
\hline
\end{tabular}

${ }^{\star} P<0.05,{ }^{* *} P<0.01,{ }^{* *} P<0.001$ 
Table 5. Factors associated with subsequent depressive symptoms according to the logistic regression analysis. $(\mathrm{OR}=$ odds ratio, $95 \% \mathrm{Cl}=95 \%$ confidence interval)

\begin{tabular}{|c|c|c|c|c|}
\hline \multirow[t]{3}{*}{ Associated factor } & \multicolumn{4}{|c|}{ Depressive symptoms } \\
\hline & \multicolumn{2}{|c|}{$\begin{array}{c}\text { Men } \\
(\mathrm{N}=6751)\end{array}$} & \multicolumn{2}{|c|}{$\begin{array}{l}\text { Women } \\
(\mathrm{N}=2308)\end{array}$} \\
\hline & OR & $95 \% \mathrm{Cl}$ & $\mathrm{OR}$ & $95 \% \mathrm{Cl}$ \\
\hline \multicolumn{5}{|l|}{$\begin{array}{l}\text { Age groups } \\
\text { (years) }\end{array}$} \\
\hline $\begin{array}{l}41-44 \\
45-49 \\
50-54 \\
55-56\end{array}$ & $\begin{array}{r}1 \\
1.02 \\
0.93\end{array}$ & $\begin{array}{l}. \\
0.91-1.15 \\
0.71-1.22\end{array}$ & $\begin{array}{r}1 \\
1.18 \\
0.88 \\
1.20\end{array}$ & $\begin{array}{l}0.93-1.50 \\
0.66-1.16 \\
0.70-2.05\end{array}$ \\
\hline \multicolumn{5}{|l|}{ Marital status } \\
\hline $\begin{array}{l}\text { Married } \\
\text { Single } \\
\text { Cohabiting } \\
\text { Separated } \\
\text { Divorced } \\
\text { Widowed }\end{array}$ & $\begin{array}{r}1 \\
1.72 \\
0.97 \\
2.88 \\
2.01 \\
1.93\end{array}$ & $\begin{array}{l}1.18-2.51 \\
0.70-1.34 \\
1.73-4.79 \\
1.53-2.63 \\
1.11-3.35\end{array}$ & $\begin{array}{r}1 \\
1.25 \\
1.37 \\
2.16 \\
1.36 \\
1.81\end{array}$ & $\begin{array}{l}0.85-1.84 \\
0.94-1.99 \\
1.14-4.10 \\
1.03-1.79 \\
1.09-3.01\end{array}$ \\
\hline \multicolumn{5}{|l|}{ Educational level } \\
\hline $\begin{array}{l}\text { Primary } \\
\text { Lower vocational } \\
\text { Lower secondary } \\
\text { Upper secondary } \\
\text { Upper vocational } \\
\text { University }\end{array}$ & $\begin{array}{r}0.80 \\
0.87 \\
1.03 \\
1.12 \\
0.88 \\
1\end{array}$ & $\begin{array}{c}0.57-1.13 \\
0.72-1.05 \\
0.82-1.29 \\
0.87-1.46 \\
0.68-1.15 \\
.\end{array}$ & $\begin{array}{r}1.05 \\
1.11 \\
1.03 \\
1.06 \\
1.12 \\
1\end{array}$ & $\begin{array}{c}0.57-1.94 \\
0.69-1.79 \\
0.62-1.71 \\
0.62-1.79 \\
0.63-1.98 \\
.\end{array}$ \\
\hline \multicolumn{5}{|l|}{$\begin{array}{l}\text { Previous absenteeism } \\
\text { for mental disorders }\end{array}$} \\
\hline $\begin{array}{l}\text { No } \\
\text { Yes }\end{array}$ & $\begin{array}{r}1 \\
5.71\end{array}$ & $3.30-9.89$ & $\begin{array}{r}1 \\
1.85\end{array}$ & $1.23-2.80$ \\
\hline \multicolumn{5}{|l|}{ Stressful personal events } \\
\hline $\begin{array}{r}0 \\
1 \\
2 \\
\geq 3\end{array}$ & $\begin{array}{r}1 \\
1.15 \\
1.58 \\
1.77\end{array}$ & $\begin{array}{l}1.01-1.31 \\
1.33-1.87 \\
1.32-2.37\end{array}$ & $\begin{array}{r}1 \\
1.53 \\
2.02 \\
3.17\end{array}$ & $\begin{array}{l}1.23-1.90 \\
1.52-2.69 \\
2.08-4.82\end{array}$ \\
\hline \multicolumn{5}{|l|}{ Occupation } \\
\hline $\begin{array}{l}\text { Teaching and health } \\
\text { professionals }\end{array}$ & 1.23 & $0.74-2.06$ & . & . \\
\hline $\begin{array}{l}\text { Managers } \\
\text { Engineers }\end{array}$ & $\begin{array}{r}1 \\
1.05\end{array}$ & $0.87-1.27$ & $\begin{array}{r}1 \\
1.07\end{array}$ & $0.56-2.03$ \\
\hline $\begin{array}{l}\text { Health and social work } \\
\text { associate professionals }\end{array}$ & & . & 1.05 & $0.43-2.59$ \\
\hline $\begin{array}{l}\text { Administrative } \\
\text { associate professionals }\end{array}$ & 1.54 & $1.22-1.95$ & 2.16 & $1.31-3.57$ \\
\hline $\begin{array}{l}\text { Physical, engineering and } \\
\text { life science associate } \\
\text { professionals }\end{array}$ & 1.44 & $1.06-1.95$ & & \\
\hline Foremen & 1.43 & $1.16-1.75$ & 2.01 & $1.15-3.51$ \\
\hline Clerks & 1.72 & $1.17-2.54$ & 2.19 & $1.27-3.77$ \\
\hline Skilled industrial workers & 1.67 & $1.17-2.37$ & . & . \\
\hline Craftsmen & 1.85 & $1.31-2.60$ & . & . \\
\hline \multicolumn{5}{|c|}{ Stressful occupational events } \\
\hline $\begin{array}{r}0 \\
1 \\
\geq 2\end{array}$ & $\begin{array}{r}1 \\
1.57 \\
1.73\end{array}$ & $\begin{array}{l}1.37-1.79 \\
1.40-2.14\end{array}$ & $\begin{array}{r}1 \\
1.44 \\
2.04\end{array}$ & $\begin{array}{l}1.14-1.82 \\
1.47-2.85\end{array}$ \\
\hline \multicolumn{5}{|l|}{$\begin{array}{l}\text { Levels of psychological } \\
\text { demands }\end{array}$} \\
\hline $\begin{array}{l}\text { Low } \\
\text { High }\end{array}$ & $\begin{array}{r}1 \\
1.77\end{array}$ & $1.57-1.99$ & $\begin{array}{r}1 \\
1.37\end{array}$ & $1.13-1.67$ \\
\hline \multicolumn{5}{|l|}{ Levels of decision latitude } \\
\hline $\begin{array}{l}\text { High } \\
\text { Low }\end{array}$ & $\begin{array}{r}1 \\
1.38\end{array}$ & $1.22-1.56$ & $\begin{array}{r}1 \\
1.41\end{array}$ & $1.15-1.73$ \\
\hline \multicolumn{5}{|l|}{$\begin{array}{l}\text { Levels of social } \\
\text { support at work }\end{array}$} \\
\hline $\begin{array}{l}\text { High } \\
\text { Low }\end{array}$ & $\begin{array}{r}1 \\
1.58\end{array}$ & $1.41-1.78$ & $\begin{array}{r}1 \\
1.29\end{array}$ & $1.06-1.57$ \\
\hline
\end{tabular}

women. However, no interaction between these 3 psychosocial factors at work was observed.

Nevertheless, these results may have been affected by certain limitations, which deserve to be considered. First, the assessment of psychosocial factors at work in 1995 was based on self-reporting, which only reflects the objective work environment in part. This assessment may therefore have been subject to a response bias. However, no adequate objective measurement is available for the psychosocial work environment. Attempts to use a jobexposure matrix have been made, but they led to an underestimation of within-occupation variance (34). As regards our scale of social support at work, it is not completely adequate, as it only measures the frequency of contacts with co-workers and not satisfaction with the support received from either co-workers or the supervisor.

Second, depressive symptoms were measured by the CES-D scale. Although self-reported measures of these symptoms do not always indicate the presence of clinical depression, these scales have been considered to measure nonspecific psychological distress (35). Moreover, strong concordance was observed between the CES-D scale and absenteeism for anxiety or depressive disorders. The prevalences of depressive symptoms observed for the men and women were similar to those found in other studies (9).

Third, to avoid any spurious association between psychosocial work variables and depressive symptoms due to confounding factors, our analyses were adjusted for most of the known or suspected mental health risk factors. In particular, adjustment for previous mental disorders, assessed from absenteeism data provided by the Company, reduced at least in part the potential influence of depressive symptoms at the time of the assessment of psychosocial factors at work in 1995. Furthermore, although psychosocial factors at work were measured only in 1995, stressful occupational events (ie, major changes in the work environment that occurred from 1995 to 1996) were taken into account as a confounding variable. However, it is possible that some confounding factors were disregarded, such as personality traits. Other authors have noted that the association between psychosocial factors at work and mental health indicators remain strong even after adjustment for mental health risk factors (15). Thus it seems unlikely that any missing confounding factors would completely explain the observed associations.

In spite of these limitations, the results of our study strongly support the possibility that psychosocial factors at work are predictive of depressive symptoms. They are consistent with the findings reported in previous crosssectional studies in which a relationship was found between psychosocial factors at work and mental health disorders $(11-16)$. Very few studies have been longitudinal $(17,18)$. The results of the longitudinal study by Carayon (18) failed to support the existence of an association between psychosocial factors at work and 
depressive symptoms, whereas the one by Bromet et al (17) showed that job demands and their interaction with co-worker support are predictors of affective disorders a year later after adjustment for age, history of affective disorders, symptoms, alcohol-related problems, marital stress, and friendship support at the beginning of the study. In our study, lack of social support at work was found to be a predictive factor of depressive symptoms, but it did not modify the relationship of job demands and decision latitude with these symptoms. Other authors have also failed to find any support for a modifying effect of social support at work (15).

Our results also underline the differences between men and women as regards the effects of occupational stress on mental health. Although high levels of job demands, low levels of decision latitude, and low levels of social support at work were all significant predictors of depressive symptoms among both the men and women, the associations were stronger for the men for psychological demands and social support at work. Very few authors have studied men and women separately. Braun \& Hollander (13) found that depression was related to high demands and low latitude for both men and women. On the other hand, men and women have different occupational roles and their work conditions may also differ (36). These differences may partly explain the differences that we observed between the patterns of depressive symptoms in relation to the psychosocial work factors for the men and women.

As regards the other risk factors considered, our study showed that both personal and occupational factors play a role in the subsequent development of depressive symptoms. There was no relationship between age and these symptoms, but the range of age was rather small in our study. Thus, in 1995, the men were aged $46-56$ years and the women $41-56$ years. Marital status and stressful personal events were strong predictors of subsequent depressive symptoms. Other authors have found similar results $(3,8,15,37)$. Note that the effects of marital status on subsequent depressive symptoms were stronger among the men, whereas the effects of stressful personal events were stronger among the women. Educational level was not a significant risk factor for subsequent depressive symptoms. Previous absenteeism for mental disorders was significantly associated with subsequent depressive symptoms; this finding was consistent with previous results (17). As regards occupational factors, occupation was related to subsequent depressive symptoms. Other authors have also observed that certain occupations carry a high risk of depressive disorders $(3,4,15,37,38)$. Others again (39) have suggested that the relationship between depressive disorders and low socioeconomic status may be partly explained by certain occupational characteristics and that jobs involving direction, control, and planning may protect against the development of depression. We also found in this study that stressful occupational events reported by the workers and defined by changes in the work content or organization are predictive of subsequent depressive symptoms; and, in this respect, our prospective results agree with those of Chevalier et al (8).

In conclusion, our results strongly support the possibility that psychosocial factors at work are predictive of depressive symptoms. As mental health disorders have a considerable impact on a population's well-being and on the economy, these results underline the need for further research on the occupational risk factors of depressive disorders and on measures to prevent such disorders.

\section{Acknowledgments}

The authors wish to thank the Medical Committee of EDF-GDF and all the participating workers of the Gazel cohort, who made the study possible. Our thanks go also to Mathilde Dreyfus for the English language revision.

\section{References}

1. Chevalier A, Luce D, Blanc C, Goldberg M. Sickness absence at the French National Electric and Gas Company. Br J Ind Med 1987;44:101-10.

2. Johnson J, Weissman MM, Klerman GL. Service utilization and social morbidity associated with depressive symptoms in the community. J Am Med Assoc 1992;267:1478-83.

3. Stansfeld S, Feeney A, Head J, Canner R, North F, Marmot M. Sickness absence for psychiatric illness: the Whitehall II study. Soc Sci Med 1995;40:189—97.

4. Eaton WN, Anthony JC, Mandel W, Garrison R. Occupations and the prevalence of major depressive disorder. J Occup Med 1990;32:1079-87.

5. Estryn-Behar M, Kaminski M, Peigne E, Bonnet N, Vaichere E, Gozlan C, et al. Stress at work and mental health status among female hospital workers. $\mathrm{Br} \mathrm{J}$ Ind Med $1990 ; 47: 20-8$.

6. Kawakami N, Haratani T, Araki S. Effects of perceived job stress on depressive symptoms in blue-collar workers of an electrical factory in Japan. Scand J Work Environ Health 1992;18:195-200.

7. Loscocco KA, Spitze G. Working conditions, social support, and the well-being of female and male factory workers. J Health Soc Behav 1990;31:313-27.

8. Chevalier A, Bonenfant S, Picot MC, Chastang JF, Luce D. Occupational factors of anxiety and depressive disorders in the French national electricity and gas company. J Occup Environ Med 1996;38:1098-107.

9. Goldberg P, David S, Landre MF, Goldberg M, Dassa S, Fuhrer R. Work conditions and mental health among prison staff in France. Scand J Work Environ Health 1996;22:4554.

10. Schnall PL, Landsbergis PA, Baker D. Job strain and cardiovascular disease. Ann Rev Public Health 1994;15:381411.

11. Karasek RA. Job demands, job decision latitude, and mental 
strain: implications for job redesign. Adm Sci Q 1979;24:285-308

12. Karasek R, Theorell T. Healthy work: stress, productivity, and the reconstruction of working life. New York (NY): Basic Books, 1990.

13. Braun S, Hollander RB. Work and depression among women in the Federal Republic of Germany. Women Health 1988;14:3-26.

14. Landbergis PA. Occupational stress among health care workers: a test of the job demands-control model. J Organ Behav 1988;9:217-39.

15. Bourbonnais R, Brisson C, Moisan J, Vézina M. Job strain and psychological distress in white-collar workers. Scand $\mathrm{J}$ Work Environ Health 1996;22:139-45.

16. Stansfeld SA, North FM, White I, Marmot MG. Work characteristics and psychiatric disorder in civil servants in London. J Epidemiol Community Health 1995;49:48 -53.

17. Bromet EJ, Dew MA, Parkinson DK, Schulberg HC. Predictive effects of occupational and marital stress on the mental health of a male workforce. J Organ Behav 1988;9:1-13.

18. Carayon P. A longitudinal test of Karasek's job strain model among office workers. Work Stress 1993;7:299-314.

19. Goldberg M, Leclerc A, Chastang JF, Morcet JF, Marne MJ, Luce D, et al. Mise en place d'une cohorte épidémiologique à Electricité De France - Gaz De France: recrutement des volontaires. Rev Epidémiol Santé Publique 1990;38:2658.

20. Goldberg M, Leclerc A, Chastang JF, Morcet JF, Marne MJ, Luce D, et al. Mise en place d'une cohorte épidémiologique à Electricité De France - Gaz De France: principales caractéristiques de l'échantillon. Rev Epidémiol Santé Publique 1990;38:378-80.

21. Niedhammer I, Goldberg M, Leclerc A, David S, Bugel I, Landre MF. Psychosocial work environment and cardiovascular risk factors in an occupational cohort in France. J Epidemiol Community Health 1998;52:93-100.

22. Boumendil E, Tubert-Bitter P. Depression-induced absenteeism in relation to antihyperlipidemic treatment: a study using Gazel cohort data. Epidemiology 1995;6:322-5.

23. Moneta GB, Leclerc A, Chastang JF, Dang Tran P, Goldberg M. Time-trend of sleep disorder in relation to night work: a study of sequential 1-year prevalences within the Gazel cohort. J Clin Epidemiol 1996;49:1133-41.

24. Ringa $V$, Ledésert $B$, Bréart $G$. Determinants of hormone replacement therapy among postmenopausal women enrolled in the French Gazel cohort. Osteoporosis Int 1994:4:16-20.

25. Johnson JV, Hall EM. Job strain, work place social support, and cardiovascular disease: a cross-sectional study of a random sample of the Swedish working population. Am J Public Health 1988;78:1336-42.

26. Johnson JV, Hall EM, Theorell T. Combined effects of job strain and social isolation on cardiovascular disease morbidity and mortality in a random sample of the Swedish male working population. Scand J Work Environ Health 1989;15:271-9.

27. Radloff LS. The CES-D scale: a self-report depression scale for research in the general population. Appl Psychol Meas $1977 ; 3: 385-401$

28. Weissman MM, Sholomskas D, Poetenger M, Prusoff BA, Locke BZ. Assessing depressive symptoms in five psychiatric populations: a validation study. Am J Epidemiol 1977;106:203-14.

29. Fuhrer R, Rouillon F. La version française de l'échelle CES-D [Center for Epidemiologic Studies-Depression Scale]: description et traduction de l'échelle d'autoévaluation. Psychiatr Psychobiol 1989;4:163-6.

30. Goldberg M, Blanc M, Chastang JF, Blanc C, Sommer M. The health data base of a nationwide company -- its use in epidemiological studies. J Occup Med 1982;24:47-52.

31. Holmes TH, Rahe RH. The social readjustment rating scale. J Psychom Res 1967;11:213-8.

32. SAS Institute Inc. SAS/STAT user's guide, release 6.03 ed. Cary (NC): SAS Institute Inc, 1988.

33. BMDP Statistical Software Inc. BMDP statistical software manual, vol 2. Los Angeles (CA): BMDP Statistical Software Inc, 1990.

34. Schwartz JE, Pieper CF, Karasek RA. A procedure for linking psychosocial job characteristics data to health surveys. Am J Public Health 1988;78:904-9.

35. Dohrenwend BP, Shrout PE, Egri G, Mendelsohn FS. Nonspecific psychological distress and other dimensions of psychopathology. Arch Gen Psychiatry 1980;37:1229-36.

36. Lennon MC. Sex differences in distress: the impact of gender and work roles. J Health Soc Behav 1987;28:290305 .

37. Kawakami N, Roberts RE, Lee ES, Araki S. Changes in rates of depressive symptoms in a Japanese working population: life-table analysis from a 4-year follow-up study. Psychol Med 1995;25:1181-90.

38. Roberts RE, Sul Lee E. Occupation and the prevalence of major depression, alcohol, and drug abuse in the United States. Environ Res 1993;61:266-78.

39. Link BG, Lennon MC, Dohrenwend BP. Socioeconomic status and depression: the role of occupations involving direction, control, and planning. Am J Sociol 1993;98:1351-87.

Received for publication: 26 July 1997 


\section{Appendix}

\section{Contents of the questionnaire on psychosocial factors at work}

\begin{tabular}{|c|c|}
\hline Psychosocial factor & Item on questionnaire \\
\hline \multirow[t]{5}{*}{ Psychological job demands } & $\begin{array}{l}\text { My work requires me to work very fast. } \\
\text { (1=strongly disagree; } 2=\text { disagree; } 3=\text { agree; } 4=\text { strongly agree) }\end{array}$ \\
\hline & $\begin{array}{l}\text { My work requires me to work very hard. } \\
\text { (1=strongly disagree; } 2=\text { disagree; } 3=\text { agree; } 4=\text { strongly agree) }\end{array}$ \\
\hline & $\begin{array}{l}\text { I am asked to do too much work. } \\
\text { (1=strongly disagree; } 2=\text { disagree; } 3=\text { agree; } 4=\text { strongly agree) }\end{array}$ \\
\hline & $\begin{array}{l}\text { I have enough time to do my work. } \\
\text { ( } 1=\text { strongly disagree; } 2 \text { =disagree; } 3=\text { agree; } 4=\text { strongly agree) }\end{array}$ \\
\hline & $\begin{array}{l}\text { I receive no conflicting demands. } \\
\text { (1=strongly disagree; } 2=\text { disagree; } 3=\text { agree; } 4=\text { strongly agree) }\end{array}$ \\
\hline \multirow[t]{6}{*}{ Decision latitude } & $\begin{array}{l}\text { My work requires me to learn new skills. } \\
\text { (1=strongly disagree; } 2=\text { disagree; } 3=\text { agree; } 4=\text { strongly agree) }\end{array}$ \\
\hline & $\begin{array}{l}\text { My work requires a high level of skills. } \\
\text { (1=strongly disagree; } 2=\text { disagree; } 3=\text { agree; } 4=\text { strongly agree })\end{array}$ \\
\hline & $\begin{array}{l}\text { My work requires creativity. } \\
\text { (1=strongly disagree; } 2=\text { disagree; } 3=\text { agree; } 4=\text { strongly agree) }\end{array}$ \\
\hline & $\begin{array}{l}\text { My work is repetitive. } \\
(1=\text { strongly disagree; } 2=\text { disagree; } 3=\text { agree; } 4=\text { strongly agree })\end{array}$ \\
\hline & $\begin{array}{l}\text { I am free to decide what I am going to do on the job. } \\
\text { ( } 1=\text { strongly disagree; } 2=\text { disagree; } 3=\text { agree; } 4=\text { strongly agree) }\end{array}$ \\
\hline & $\begin{array}{l}\text { I am free to decide the amount of work I am going to do. } \\
\text { (1=strongly disagree; } 2=\text { disagree; } 3=\text { agree; } 4=\text { strongly agree) }\end{array}$ \\
\hline \multirow[t]{5}{*}{ Social support at work } & $\begin{array}{l}\text { Can you talk to your co-workers during breaks? } \\
\text { ( } 1=\text { yes, often; } 2=y e s, \text { sometimes; } 3=\text { no break; } 4=\text { no break with co-workers) }\end{array}$ \\
\hline & $\begin{array}{l}\text { Can you leave your work to talk to your co-workers? } \\
\text { (1=yes, often; } 2=\text { yes, sometimes; } 3=\text { no, almost never; } 4=\text { no, never) }\end{array}$ \\
\hline & $\begin{array}{l}\text { Does your work require many contacts with your co-workers? } \\
\text { (1=yes, often; } 2=y e s, \text { sometimes; } 3=\text { no, I work mainly alone; } 4=\text { no, I work completely } \\
\text { alone) }\end{array}$ \\
\hline & $\begin{array}{l}\text { How often do you meet your co-workers outside the workplace? } \\
\text { (1=one time or more a week; } 2=\text { one time or more a month; } 3=\text { one time or more a year; } \\
4=\text { never })\end{array}$ \\
\hline & $\begin{array}{l}\text { When did you last meet one of your co-workers at home? } \\
\text { ( } 1=\text { one month or less ago; } 2=1-12 \text { months ago; } 3=\text { more than one year ago; } 4=\text { never) }\end{array}$ \\
\hline
\end{tabular}

